\title{
India-Iran Relations and the Global World
}

\author{
Yasmeena Ara \\ Research Scholar, (CCAS) University of Kashmir, India \\ E-Mail: Jasminemohammad82@gmail.com
}

\begin{abstract}
India and Iran being neighbours have been historically and culturally connected. Both share a long tradition of ideas since civilizations. Both countries had linkages since the pre-historic times. Various historical leftovers found in India resemble those with those found in Dejleh and Forat rivers in Iran show that both nations had cordial interactions with each other. However with the passage of time different factors erupted in between the two, particularly after end of Cold War. U.S. and Israel have affected ties between the two. India-Iran relations have been subject to several factors; be it regional or global. At regional level, Pakistan, Afghanistan, China, and the Central Asian region and globally US and Israel have played major role. The present study is a humble attempt to analyse the impact and effect of global factors in Indo-Iranian relations.

Keywords: Factors, US, Israel, Relations, Cold War, India, Iran
\end{abstract}

\section{INTRODUCTION}

India and Iran have close relations since early times. It was until partion and creation of Pakistan, that India shared long border with Iran [1].

"Few people have been more closely related in origin and throughout history than the people of India and the people of Iran" [2].

$$
\text { -Jawaharlal Nehru }
$$

Both countries had political, cultural and other linkages since the pre-historic times. Various historical leftovers found in India resemble those with those found in Dejleh and Forat. Rivers in Iran show that both nations had cordial interactions with each other. Interactions between the two old civilizations, i.e. Indus valley civilization and the Elamite civilization of Persia were a common thing [3].

\section{RELATIONS AFTER INDIA'S INDEPENDENCE}

After India gained independence and followed the policy of non-alignment, ties between Iran and India became loose. Iran aligned with the west [4]. Iranian ruler Mohammad Reza Shah Pahlavi wanted the Red Army of Soviet Union to leave Iranian territory and watching the reluctance on their part, he leaned towards the west and entered the Central Treaty Organisation (CENTO). Nehru had declared the CENTO as "a wrong approach, dangerous and a harmful approach".

Here it is worth mentioning that Nehru's support for antimonarchical Jamal Abdul Nasser of Egypt added to the Shah's hard attitude towards India. This led to support of Shah towards creation of Islamic bloc and closer ties between Iran and Pakistan [5]. All this prevented strong ties between the two nations. Yet diplomatic ties were established between the two. There were visits and reciprocal visits by the heads of the two nations [6]. However, certain factors never let India Iran relations to grow on faster pace. Iran supported Pakistan during India Pakistan war (1965) with nurses, medical supplies, and a gift of 5,000 tons of petroleum. Iran also supported Pakistan by supplying military equipments. India was very much dissatisfied with Iran's stance over Kashmir and its support for Kashmiri aspirations [7].

After the Islamic revolution of Iran in 1979, the development of bilateral relations stopped. Iran was busy in consolidating its internal conditions. Before the revolution, Iran had close ties with US. However, after revolution, it tried to review these ties and kept itself aloof from Afghanistan. Although it had sympathy with jihad in Afghanistan but it knew that, it was sponsored by US. It was in 1983 that India and Iran established a joint commission to strengthen security ties between the two [8]. End of Cold War and the New World Order gave a new flip to the existing India-Iran relations. Both agreed to enhance their economic and technical ties and to cooperate in security issues [9].

\section{A NEW PHASE OF RELATIONS}

In 1990's, India opened its economy and it became necessary for India to foster ties with energy rich nations. Iran with its vast hydrocarbon resources attracted Indian attention [10]. Consequently, India Iran relations started to grew when Prime Minister Narsimha Rao visited Iran in 1993. This was first Indian Prime ministerial visit from India after Islamic revolution in Iran in 1979. This visit was followed by a reciprocal visit by President of Iran Akbar Hashemi Rafsanjani in 1995. An agreement was also signed between India, Iran and Russia to establish a North-South Transportation Corridor which will link India via Iran to Russia and then to Europe [11]. This time Iran asked India to provide spare parts and experiences of Indian navy [12]. However, the historic visit by Indian Prime Minister Vajpayee in 2001 and the reciprocal visit by Iranian President Khatami in 2003 are important milestones in India-Iran relations [13]. The 2001 visit by Indian PM led to the signing of "Tehran Declaration" followed by six MoUs including the "Memorandum of Understanding on the Road Map to Strategic Cooperation" [14]. Indian foreign secretary Kanwal Sibal in September 2003 emphasized the 
significance of India-Iran relations and said, "There should be no doubt of the strategic importance New Delhi attaches to the relationship." The 2003 "Delhi Declaration" between the two countries energized the relations in the military area through Sea-lane control and security, Indo-Iran joint naval exercises, upgrading Iran's Russian made defence systems and a joint working team on counter-terrorism and counternarcotics. Delhi agreement came at the time when U.S. was busy in building up its military in Persian Gulf for invading Iraq and in expanding US-Indian military ties [15].

India and Iran now decided to take concrete steps regarding oil and gas projects and to take joint efforts to develop the Chabahar Port, the Chabahar-Fahranj-Bam railway link and Marine Oil Tanking Terminal. Delhi Declaration announces "The republic of India and the Islamic republic of Iran are resolved to exploit the full potential of the bilateral relationship in the interest of the people of the two countries and of regional peace and stability... With a vision of a strategic partnership for a more stable, secure and prosperous region and for enhanced regional and global cooperation...explore opportunities for cooperation in defence in agreed areas, including training and exchange of visits" [16].

\section{INDIA'S LOOK WEST POLICY}

Soon after it opened up its economy and the global political scenario got changed by the disintegration of USSR, India's policy formulations shifted towards its neighbourhood. India in early 1990's had launched "Look East Policy" and on the same lines, "Look West Policy" was launched in 2005. India after realising the strategic importance of Iran and the Persian Gulf and its vital stakes, launched this policy [17].

Iran finds prominent place in India's Look West policy due to it being India's "proximate neighbourhood." Iran is geostrategically important for India and its influence over Straits of Hormuz make it an important country in the region. India's growing energy needs make Iran an important country for India. Iran owns the third largest proven oil reserves and second largest proven gas reserves of the world. Another area was Iran finds an important place for India is maritime security [18]. Iran with its unique geostrategic location has emerged as a gateway for India to entre Central Asia. Iran has become an integral part for the India's trade with Europe and Afghanistan. The rising nonsecurity threats of terrorism and extremism from Central Asia and Afghanistan is an important area of cooperation between the two nations [19].

At global level when we see both states are not comfortable with the unipolarity and seek to undermine it. For both the states, the Sunni extremism is a threat. Iran is a largest Shia state and India is the third largest Shia state in the world [20]. Through Iran, India is able to fulfil variety of tangible and specific Indian interests, the important one being India's energy needs. Being the fourth largest economy in terms of
PPP, Indian oil and energy needs are growing. In this connection, Iran is significant from different aspects. Iran at the first instance will remain India's preferred choice as import market for energy and secondly will provide India a preferred transit route for natural gas from Central Asian region. Along with Iran, India can further strengthen its stance in Afghanistan. Iran can also prove to be a better option for India to deepen and enlarge its sway in the Indian Ocean region. Iran provides India a chance to extend its influence from the Strait of Hormuz to the Strait of Malacca and from the coast of Africa to the western shores of Australia as it is part of this geography [21].

\section{EXTERNAL FACTORS IN INDO-IRANIAN RELATIONS}

\section{A. U.S. Factor}

Cold war witnessed two super Powers in International arena. However, once Cold War ended and the Eastern bloc disintegrated, global world order entered unipolar phase with US as only super power.

Mohammad Reza Pahlavi ruled Iran until Islamic revolution of 1997. Shah wanted to modernise Iran and was anticommunist, which US took as an opportunity to contain Soviet influence from the Middle Eastern region. United States became an ally of the Mohammad Reza Pahlavi. However, Ayatollah Ruhollah Khomeini who was exiled by Shah in 1964 organised a mass uprising, returned to Iran February 1, 1979, and, on February 11, 1979, he declared Iran as Islamic Republic. Shah's government was toppled down. Khomeini's regime was based on strong opposition to Western influence. Relations between the two turned hostile when pro-Khomeini supporters seized US embassy. US diplomats were kept in hostage and before two weeks of a failed military attempt to rescue the hostages, United States broke relations with Iran on April 7, 1980. Since then Iran is following policies hostile to US interests in the 'Near East' region and beyond. It resulted into imposition of trade related sanctions on Iran. When Iran advanced its nuclear program, US along with other European nations tried to persuade Iran to limit its nuclear program. President Bush on January 20, 2005 stated that the United States would be a close ally of a "free and democratic" Iran [22]. Iran denied and continued to advance its nuclear program. After the International Atomic Energy Association (IAEA), the UN's nuclear watchdog, in September 2005 found that Tehran was not compliant with its international obligations, United States, United Nations, and European Union levied multiple sanctions on Iran. US pressurised international community to isolate Tehran financially and block its oil exports to make it to come on the table [23].

India being a responsible member of international community, largely implemented the UN sanctions on Iran. But was hesitant to impose sanctions mandated by US and EU. India was not ready for the negative impact that the third party sanctions could have. US led international 
sanctions against Iran have subdued India-Iran ties largely. India is the fourth largest importer of oil and petroleum products. So India's policy makers are well aware of the need to diversify the sources of energy supply. India's majority of oil imports come from the Middle East. IndoIran bilateral trade as it was forced to reduce its crude oil imports from Iran. Between 2017-18, India imported 27.2 million tons of crude worth of $\$ 11.1$ billion from Iran [24]. US pressure to cut the oil imports from Iran made India alert about its extant energy ties and the potential for cooperation in this sector. The energy aspect in indo-Iran relations irritated the indo-US ties [25].

The continued US pressure and the Indo-US nuclear deal made India to compromise with the indo-Iran ties to some extent, if not totally. Although India claimed the reasons to be security and pricing issues, yet the reality was that after US opposed the Iran-Pakistan-India (IPI) project, India shelved it. Moreover, US congress passed such Acts like Iran sanctions Act, the comprehensive Iran sanctions, Accountability and Divestment Act 2010 (CISADA), which made it very difficult to develop energy relations with Iran. CISADA maintained a condition of imposing sanctions against those foreign companies, which would invest more than \$20 million annually in Iranian energy sector. It resulted into non-realisation of several deals like a \$22 billion LNG deal signed by India's Gas Authority of India Limited (GAIL) and National Iranian Gas Export company (NIGEC) in 2005. Indian strategists and policy makers realised that close ties with US are necessary, but at the same time, India cannot afford to ignore Iran not because of the economic reasons but for geopolitical reasons too. India on the one hand refused to be a satellite state for US on Iranian issue and on the other hand tried to balance the two. One cannot be the substitute of other [26]. One the one hand India has always voted in favour of international Atomic Energy Agency's (IAEA) resolutions over Iran's nuclear issue and on the other is repeatedly emphasizing the need for a dialogue and diplomatic means for resolving the Iranian crisis [27].

\section{B. Israel Factor}

India Iran relations have been determined by many external factors. One among them is Israel factor. While India remained closely linked with Iran, it never restricted its ties with the rival nations of Iran like Israel and US. The reason is that India cannot afford to neglect US and Israel in its defence sector. In near future Iran alone may not be sufficient to fulfil Indian energy demands. Iran often complaints that India has delayed many of the decisions regarding Tehran, say IPI. However, India added the delay factor in its diplomacy in order to fulfil its national interests. It can be better understood by this that India knew that its engagements within the Middle Eastern region will increase its bargaining power in the region. In international relations, time is a major factor behind success. Decisions must be dependent on prudence. Indian approach of gradual reengagement was motivated by the uncertainty surrounding
Iran's petroleum legislation and its rehabilitation into the international financial system [28].

Present hostility between Iran and Israel hides the cooperation between the two before and after the Islamic revolution of Iran. Due to some geopolitical reasons, both cooperated in the areas of military, economy and intelligence. Iran had a fear of Jamal Abdul Nasser's concept of Pan-Arabism of Sunni majority and the Soviet Communism. Although Shah of Iran had supported the Palestinian cause, still the Sunni dominated Pan-Arabism stopped him from ignoring Israel. The pragmatic relations continued between Iran and Israel till 1980's and 1990's saw open rivalry between the two in the Middle Eastern region. Iran never saw Israel as a direct threat rather Zionist influence on US policies towards Iran has motivated Iranian rivalry towards Israel [29].

India started its diplomatic ties with Israel in 1992. It was the time when India had opened up its economy and had given a boom to its ties with Iran. Disintegration of USSR had also changed the global scenario and India now tried to compartmentalise its ties with Israel and Iran. India applied the realistic principle that in order to maximise the gains, a nation must act according to prudence and practicality. However, with time India found it difficult to maintain the balance between Israel and Iran over the issue of Iran's nuclear programme [30]. The demise of USSR, one of the two main ideological blocks since 1945 changed the international scenario. Ideologies lost their rigidity. Now nations realised that one alignment is not enough to run the foreign policy. In order to maximise their gains, nations went for diverse alignments. It was followed by India. Although during Cold War, India had not openly declared its alignments with any particular bloc and followed the policy of non-alignment. After Cold War, India opened its foreign policy orientations and reformulated it towards eastern and western neighbours [31]. While on the one hand Iran has not let its regional rival to come in between its ties with India, Israel on the other hand has expressed its concern over Indo-Iran ties. Iran calls for destruction of the Jewish state, India cannot cross the red lines [32].

\section{Present Scenario}

After Iran further advanced its nuclear program, in July 2012 the Obama Administration took two more actions to further isolate Iran for its refusal to live up to its international obligations regarding its nuclear program. These steps were to deter Iran and curtail any other country from establishing payment mechanisms for the purchase of Iranian oil. It led to significant decrease in the export of Iranian exports [33].

The sanctions as a diplomatic step got success on November 24, 2013, when the Joint Plan of Action or what is internationally called as JPOA as an interim nuclear accord was established. On January 20, 2014, JPA was implemented. Finally, on July 14, 2015, Iran and the P5+1 
[34] reached a framework called Joint Comprehensive Plan of Action (JCPOA). On 16 January 2016, IAEA certified that Iran had completed the JCPOA Nuclear-related tasks for implementation and US, UN and EU lifted off most of the sanctions on Iran. Later Trump administration pledged to renegotiate the deal to strictly enforce its terms on Iran. United States alleged Iran for not complying with the terms of the deal and unilaterally pulled out from Joint Comprehensive Plan of Action (JCPOA) between Iran and five UN permanent members and Germany [35].

Whenever sanctions were imposed on Iran, India had to face the consequences. US has threatened India of imposing sanctions for trade with Iran. India that is importing a large quantity of oil from Iran, sanctions on Tehran may disrupt Indian economy. India imports perhaps nearly $10 \%$ of its crude oil requirement. Freight for Iranian oil has increased only after few weeks of US sanctions, as many foreign shippers are not willing to carry Iranian oil. Indian imports are more than exports to Iran. India imports worth approximately $\$ 9$ billion of oil from Iran where as India exports around $\$ 3$ billion worth of goods to Iran. As oil is the main exporting commodity for Iran, recent US sanctions would target it. However, Minister of External Affairs of India, Sushma Swaraj has indicated that India will be continuing its trade with Iran despite US sanctions against it. Making it clearer, she said that India only recognises UN sanctions [36]. Energy ties have always acted as a pillar in Indo-Iranian ties, which can get a set back after new sanctions imposed on Iran. The announcement of Reliance Industries, owner of the world's largest oil refining complex and chief purchaser of Iranian crude, that it would cease oil imports from Iran in October or November because of the sanctions risk from the United States is enough to understand the impact of US sanctions. The data here substantiates the statement that in 2017 Reliance imported approximately 67,000 barrels per day (bpd) of crude from Iran, which went up to 96,000 bpd for the first quarter of 2018. Currently India is importing 604,000 bpd from Iran. The decision by Reliance will reduce it by more than $15 \%$ alone [37]. Several factors can lead to warmer ties between India and Iran. One of the foremost elements in indo-Iranian ties is that India has $10-15 \%$ of the world's Shia population, which binds it with the Shia majority Iran [38]. The Chabahar port will give boost to indo-Iranian economic and strategic cooperation. This port connecting India, Iran and Afghanistan bypassing Pakistan, reflects growing convergence of interests among the three countries. It will not only give India access to Afghanistan and Central Asia but also will help India in receiving natural gas imports from Iran. This port can serve as a point of origin for the proposed Iran-Oman-India pipeline [39].

However, India's involvement in Iran's Chabahar port is seen as an effort to counter Pakistan's Gwadar port, to put a check on Chinese activities in the Indian Ocean region. On 3 December 2017, its first phase was inaugurated and is highly accessible from India's Western Coast. This port s viewed as a gateway for India, Iran and Afghanistan to enter the Central Asian region [40]. Pakistan and China can be main challenges for India to counter with as far as their ties with Iran are concerned. Pakistan is trying its level best to maintain neutrality in the Iran-Saudi tussle. Again, Pakistan is acting as a mediator for the reconciliation process in Afghanistan for which Iran is showing full support. On the other hand, Iran's ties with China are growing and it is evident from the fact that China imports approximately 50\% of Iran's total crude oil exports. Iran is cooperating with Pakistan in terms of energy also. Iran has completed its part of the pipeline to Pakistani border. Pakistan is ready to complete its section of $80 \mathrm{~km}$ once the sanctions are lifted formally. China is realistically taking the steps and supports this pipeline as it has a geopolitical potential to mould this pipeline in its favour [41]. Middle East has also witnessed internal strife and Iran is not the only Middle Eastern country where India is involved. Saudi Arabia and the other Gulf Cooperation Council (GCC) are suppliers of significant amount of oil to India. Therefore, India not only needs to balance Iran and US but also the Gulf nations [42].

\section{CONCLUSION}

Thus to conclude, we can say that though the Indo-Iranian ties are historically connected, the external factors particularly US and Israel have played significant role in shaping the Indo-Iranian relations. India and Iran ties have passed through different phases and effects of factors is clearly observable. Regionally Pakistan and China have affected the Indo-Iranian ties largely. The growing extremism, which can have impact on both India and Iran, can turn both to cooperate for its eradication. The new threat of IS which is particularly showing anti-Iran and anti-Shia tendency can motivate Iran to cooperate with India. Sanctions over Iran can to some extent favour India as Iran may be looking for an Asian neighbour for which India is best suitable. As Iran's main export commodity is oil so it may offer India better incentives to continue its oil imports from Iran.

\section{REFERENCES}

[1] Rowden, R. (2017). Understanding Foreign Relations Between India and Iran. Retrieved from http://speri.dept.shef.ac.uk/2017/07/12/ understanding-foreign-relations-between-india-and-iran/

[2] Embassy of India, Tehran Iran. Retrieved from https://www.indian embassy-tehran.ir/pages.php?id=17

[3] Ahmad, F. (2011). India's Engagements with Iran: A Geo-Economic Perspective, A. Alam, (Eds) India and Iran: An Assessment of Contemporary Relations, New Century Publications, New Delhi, 258.

[4] Berlin, Donald L. (2004). India-Iran Relations: A Deepening Entente, Asia-Pacific Center For Security Studies, 2

[5] Cheema, S. Ashwarya. (2014). Essays on Iran and Israel: an Indian Perspective, KW publishers, New Delhi, 56-57.

[6] Behuria, Ashok K. (2011). India and Iran: In Search Of A New Rhythm, A. Alam (Eds). India and Iran: An Assessment of Contemporary Relations, New Century Publications, New Delhi, 52.

[7] Berlin, Donald L. (2004). India-Iran Relations: A Deepening Entente, Asia-Pacific Center For Security Studies, 2.

[8] Behuria, Ashok K. (2011). India and Iran: In Search of A New Rhythm, A. Alam (Eds). India and Iran: An Assessment Of 
Contemporary Relations, New Century Publications, New Delhi, 5253

[9] Cheema, S. Ashwarya. (2014). Essays on Iran and Israel: an Indian Perspective, KW publishers, New Delhi, 25.

[10] Behuria, Ashok K. (2011). India and Iran: In Search Of A New Rhythm, A. Alam (Eds). India and Iran: An Assessment Of Contemporary Relations, New Century Publications, New Delhi, 53

[11] Berlin, Donald L. (2004). India-Iran Relations: A Deepening Entente, Asia-Pacific Center For Security Studies, 2.

[12] Cheema, S. Ashwarya. (2014). Essays on Iran and Israel: an Indian Perspective, KW publishers, New Delhi, 53.

[13] Berlin, Donald L. (2004). India-Iran Relations: A Deepening Entente, Asia-Pacific Center For Security Studies, 2.

[14] Cheema, S. Ashwarya. (2014). Essays on Iran and Israel: an Indian Perspective, KW publishers, New Delhi, 54.

[15] Berlin, Donald L. (2004). India-Iran Relations: A Deepening Entente, Asia-Pacific Center for Security Studies, 2-3.

[16] Mousavi, Mohammad A. (2011). Indo-Iran Relations Since New Delhi Declarations, A. Alam (Eds), India And Iran: An Assessment Of Contemporary Relations, New Century Publications, New Delhi, 33.

[17] Cheema, S. Ashwarya. (2014). Essays on Iran and Israel: an Indian Perspective, KW publishers, New Delhi, 1.

[18] Pradhan, P. Kumar. (2011). Accelerating India's "Look West Policy" in the Gulf, IDSA Issue Brief, 3

[19] Cheema, S. Ashwarya. (2011). Indo-Iranian ties: is there an Israel factor, A. Alam(Ed), India and Iran: An Assessment Of Contemporary Relations, New Century Publications, New Delhi, 177-78.

[20] Mousavi, Mohammad A. (2011). Indo-Iran Relations Since New Delhi Declarations, A. Alam (Eds), India And Iran: An Assessment Of Contemporary Relations, New Century Publications, New Delhi, 35.

[21] Berlin, Donald L. (2004). India-Iran Relations: A Deepening Entente, Asia-Pacific Center For Security Studies, 3.

[22] Katzman, Kenneth. (2018). Iran: Internal Politics and U.S. Policy and Options, Congressional Research Service, 1-24.

[23] Laub, Z . (2015). International Sanctions on Iran, Council on Foreign Relations. Retrieved from https://www.cfr.org/ backgrounder/ international-sanctions-iran, accessed on 21-09-18

[24] India imported 27.2 million tons of crude worth of $\$ 11.1$ billion between 2017-2018.

[25] Cheema, S. Ashwarya. (2014). Essays on Iran and Israel: an Indian Perspective, KW publishers, New Delhi, 104-126.

[26] Cheema, S. Ashwarya. (2014). Essays on Iran and Israel: an Indian Perspective, KW publishers, New Delhi, 13-14.

[27] Shebonti, R. D., \& Mahtab, M. A. R. (2010). US Sanctions on Iran and their Impact on India. Institute for Defence Studies and Analyses (IDSA), New Delhi, 8-9.

[28] Kumar, V. (2016). India-Iran Relations: Part One-Understanding the "Delay" Factor. Future directions international. http://www.future directions.org.au/publication/india-iran-relations-part-one-under standing-delay-factor/ accessed on 22-09-18.

[29] Kaye, D. D., Nader, A., \& Roshan, P. (2011). Israel and Iran: A Dangerous Rivalry. Rand National Defense Research Inst Santa Monica Ca, 9-65.

[30] Cheema, S. Ashwarya. (2014). Essays on Iran and Israel: an Indian Perspective, KW publishers, New Delhi, 49.

[31] Kumaraswamy, P.R. (2011). Looking West 2: Beyond the Gulf. D. Scott (Eds) Handbook of India's International Relations, 179-80.

[32] Cheema, S. Ashwarya. (2011). Indo-Iranian ties: is there an Israel factor, A. Alam(Eds). India And Iran: An Assessment Of Contemporary Relations. New Century Publications, New Delhi, 182-83

[33] The White House, Office of the Press Secretary, July 31, 2012, Retrieved from https://obamawhitehouse.archives.gov/the-press office/2012/07/31/fact-sheet-sanctions-related-iran accessed on 2909-18.

[34] P5+1 means the Permanent Five members of security council i.e. US, UK, Russia, China and France and 1 means Germany.

[35] Kerr, Paul K. \& Katzman,K. (2018). Iran Nuclear Agreement and U.S. Exit, Congressional Research Service. P.1, Retrieved from https://fas.org/sgp/ crs/nuke/R43333.pdf accessed on 29-09-18

[36] Sudhaman, K. R. (2018). Indo-Iran Trade Ties At A Crossroads After US Sanctions. Retrieved from https://www.dnaindia.com/ business/report-indo-iran-trade-ties-at-a-crossroads-after-ussanctions-2628874 accessed on 29-09-18

[37] Desai, Ronak D. (2018). With U.S. Withdrawal From The Iran Deal, Expect India-Iran Oil Trade To Take A Hit. Forbes. https://www.forbes.com/sites/ronakdesai/2018/06/11/with-u-swithdrawal-from-the-iran-deal-expect-india-iran-oil-trade-to-take-ahit/\#3b5abd0325c8 accessed on 30-09-18

[38] Madan, Tanvi. (2014). India's Relationship with Iran: It's Complicated, BROOKINGS, Retrieved from https://www.brookings. edu/blog/markaz/2014/02/28/indias-relationship-with-iran-itscomplicated/ accessed on 30-09-18.

[39] Kaura, Vinay. (2015). India and Iran: Challenges and Opportunity, The Diplomat. Retrieved from https://thediplomat.com/2015/09/ india-iran-relations-challenges-and-opportunity/accessed on 29-0918.

[40] Balasubramanian, Malavika. (2018). Indo-Iran Relations: A Timeline of Patchy and Sporadic Cooperation. The Quint. https://www.thequint.com/news/india/india-iran-relations-a-timeline accessed on 30-09-18.

[41] Kaura, Vinay. (2015). India and Iran: Challenges and Opportunity, The Diplomat. Retrieved from https://the diplomat.com/2015/09/ india- -relations-challenges-and-opportunity/ accessed on 29-09-18

[42] Madan, Tanvi. (2014). India's Relationship with Iran: It's Complicated, BROOKINGS, Retrieved from https://www.brookings. edu/blog/markaz/2014/02/28/indias-relationship-with-iran-itscomplicated/ accessed on 30-09-18. 